\title{
A NOVEL METHOD FOR DETERMINING A NEWBORN BABY'S IDENTITY BASED ON FINGERPRINTS
}

\author{
Komlen G. Lalović ${ }^{a}$, Ivan A. Tot ${ }^{\mathrm{b}}$, Mladen B. Trikoš ${ }^{\mathrm{c}}$ \\ a ITS - Information Technology School, Belgrade, Republic of Serbia, \\ e-mail: komlen.lalovic@its.edu.rs, \\ ORCID iD: (1Dhttp://orcid.org/0000-0002-4590-2185 \\ ${ }^{\mathrm{b}}$ University of Defence in Belgrade, Military Academy, Department for \\ information systems and telecommunication engineering, \\ Belgrade, Republic of Serbia, \\ e-mail: ivan.tot@va.mod.gov.rs, \\ ORCID iD: (Dhttp://orcid.org/0000-0002-5862-9042 \\ ${ }^{c}$ University of Defence in Belgrade, Military Academy, Department for \\ information systems and telecommunication engineering, \\ Belgrade, Republic of Serbia, \\ e-mail:mladen.trikos@va.mod.gov.rs, \\ ORCID iD: (i)http://orcid.org/0000-0002-5243-1326
}

DOI: 10.5937/vojtehg67-18709; https://doi.org/10.5937/vojtehg67-18709

\author{
FIELD: IT, Patent \\ ARTICLE TYPE: Original Scientific Paper \\ ARTICLE LANGUAGE: English
}

\begin{abstract}
Summary:
This work presents a novel method for biometric identity verification for newborn babies in maternity wards based on fingerprint minutiae. The information system realized combines contemporary program languages such as: Java and Python as object-oriented languages, C programming language for device programming as structural (line) and SQL for storing encrypted data in a relational database management system. Also, there is the RSA asynchronous cryptographic algorithm as well as keys for storing the encrypted data of fingerprint minutiae. The information system implements a device for biometric verification of maternity i.e. a dual fingerprint scanner that provides data of mother's and baby's fingerprints at the very moment of childbirth and further guarantees maternity for each newborn baby with $100 \%$ accuracy, by generating a unique ID reference and encrypting these data with cancelable biometrics. This is a novel method for determining identity based on baby's fingerprint minutiae.
\end{abstract}

Keywords: biometry, fingerprint, security, baby, method, information system.

ACKNOWLEDGMENT: The authors thank the Ministry of Defence of the Republic of Serbia through VA-TT/3/18-20 project. 


\section{Introduction}

Biometry is a scientific and technological discipline that measures and analyzes biological characteristics of people. It is part of advanced security systems widely used in today's modern society and protection systems.

Fingerprints and their minutiae represent the highest level of persistence in biometry and the lowest possibility of compromising the data - that is why the aim of this novel approach is based on it, implementing a device for biometric identification based on this part of biometry.

This device scans fingerprints and put into storage encrypted personal data in order to prevent any possible theft or switching of babies' identity with $100 \%$ accuracy. It has one goal - to confirm maternity for each newborn baby in hospitals. Scanning finger minutiae from both the baby and the mother, at the same time, at the very moment of childbirth, generates a unique reference and binds it with scanned data. It provides total protection and removes potential fears - it is a guarantee of identity. By encrypting these data, the whole process is raised to the highest level of security in any maternity ward worldwide. This novel method completely removes fear that almost every mother has in this period, i.e. it removes the question: "Is this my baby?". This method presents a new implementation of information technology security in the public health system and upgrades it to a higher level.

This novel method encapsulates three main parts: information system, device for biometric identification of a newborn baby, and procedures needed to be realized so that the new approach could be implemented. It solves one huge human problem - possible theft or switching of identities of newborn babies; it also removes fears that women have at the moment of childbirth, and makes it easier for gynaecologists, midwives and nurses.

This work will also present all the functionality that the device possesses, how to build the model (in figures), a picture of a cross-state and how it is designed and developed. We will give possible advantages and benefits representing a qualitative leap in public health care systems, precisely in maternity wards over the globe.

It is possible to establish wireless communication and storage types for fingerprints scanned from mothers and babies simultaneously at the moment of childbirth and generated with a unique identity reference which will be encrypted and will guarantee maternity in $100 \%$ for every baby. 
The innovation is placed in the field of Applied Information Technology, Biometry Systems: the device will be a dual fingerprint scanner - with two fields scanning simultaneously (one mother's and one baby's finger); after that, the device will allocate a unique Identification reference which will be the Identifier for each mother-baby pair for every newborn baby in maternity wards. It is listed in the International Classification of Patents, classified under G06F21/00 i.e. Biometry Systems.

\section{Solving a technical problem}

The main technical problem which has to be solved with this new method consists of:

- Building a solution for our device - a dual fingerprint scanner for scanning fingers of the mother and the baby at the very moment of childbirth. This device will differ slightly from today's existing classic fingerprint scanners - it will have two fields for scanning fingers of two different persons (mother and baby). After this process, the device will encrypt data and store them.

- It will be effective, highly practical and easy to work with, easy to control and manipulate. Its maintenance is easy, classic and similar to other fingerprint scanners. Besides scanning two fingers of different persons at the same moment, it will provide a unique ID reference (like a Primary Key) which will be a basis for every scanned mother-baby pair.

- The realised Information system (IS) presents an optimal solution for this type of work defining strict procedures needed to be obeyed. Also, the IS will implement IT technology in public health systems.

\section{Main technological overview}

In today's known technical devices, various fingerprint scanners use secure algorithms to determine and verify identity of individuals. In the Serbian National Patents base, there are no similar devices which consider this aim; namely, there are no dual biometric scanners which contain their own light and power supply. (Kaplan-Sandquist et al, 2014, pp.68-77)

Today's biometrics devices can scan one or more fingers from one person, and then from another person, but there are not fingerprint scanners which scan fingers of two different people at the same time on one device, especially not devices which during scanning create a unique reference which will be linked to the record of fingerprints scanned and earlier stored data. (Elgendi, 2012, pp.14-25) 
This scanner will possess two fields for scanning one or more fingers of two different people (mother and baby) and in that moment will generate a unique ID reference which will secure that record of fingerprints.

The question is: Can Biometry and its part - fingerprint scanning be applied for two people at the same time with one device?

It definitely can, and it will be realized with high quality, which will be shown in this work and Patent - Innovation presentation. This is a device for biometric verification of maternity. Further development of the functionality of this device will deal with the implementation of encrypted data which will carry the information about two people (mother and baby) and will be bound by a unique ID reference.

Today's patents and devices and present scanners do not have similar functions, and, most importantly, do not have a fingerprint scanning possibility for two people at the same time.

The published Patent Confirmation 13848069.4 of April $2^{\text {nd }} 2013$, with Remark WO2014059761 and Classification G06F21/00, shows a classic scanner named "Fingerprint identification device", describing a device which has a scanning function and acquires data about a fingerprint of a person (extractor software for minutiae ${ }^{1}$ ). (Moujahdi et al, 2014, pp.189-196), (Elgendi, 2012, pp.14-25)

However, this device does not have two fields for scanning fingers of two different people at the same time, which in the same time generates a unique unchangeable ID reference which will be an additional guarantee of person's identity and a guarantee of maternity for each newborn baby.

Another important aspect is the question of economy and time needed for scanning both persons' fingerprints with supporting information technology $(I T)$ in the future of the existing system which now provides only one person's data. This innovative device provides improvements in economy and time spent during the process of scanning, enabling lower costs for each device, with benefits of less time needed for processing data obtained from an image of the finger scanner. The device also gives an optimal solution for the resource usage in the case of processing data acquired during the process of fingerprint scanning, particularly when considering the memory usage and the activity of the microcontroller - the Central Processing Unit $(C P U)$.

\footnotetext{
${ }^{1}$ Minutiae - fingerprint specific points visible on a finger image
} 
Finally, regarding all these benefits, both hardware and software, the device will provide a qualitative jump in health care systems of every country where it is implemented as well as in IT industry - Biometry in particular.

\section{Information system}

The Information system created for this new method of baby identification based on fingerprints consists of parts for acquiring data, encrypting, storing and verifying data. The next step is following the procedures needed to be done. The figures show the Use Case and the Sequence diagram for this Information system.
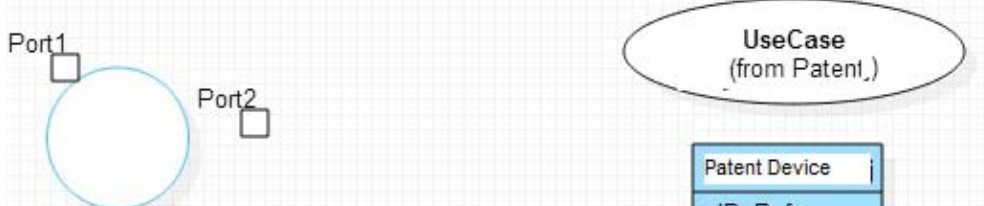

\section{GUI hospital}
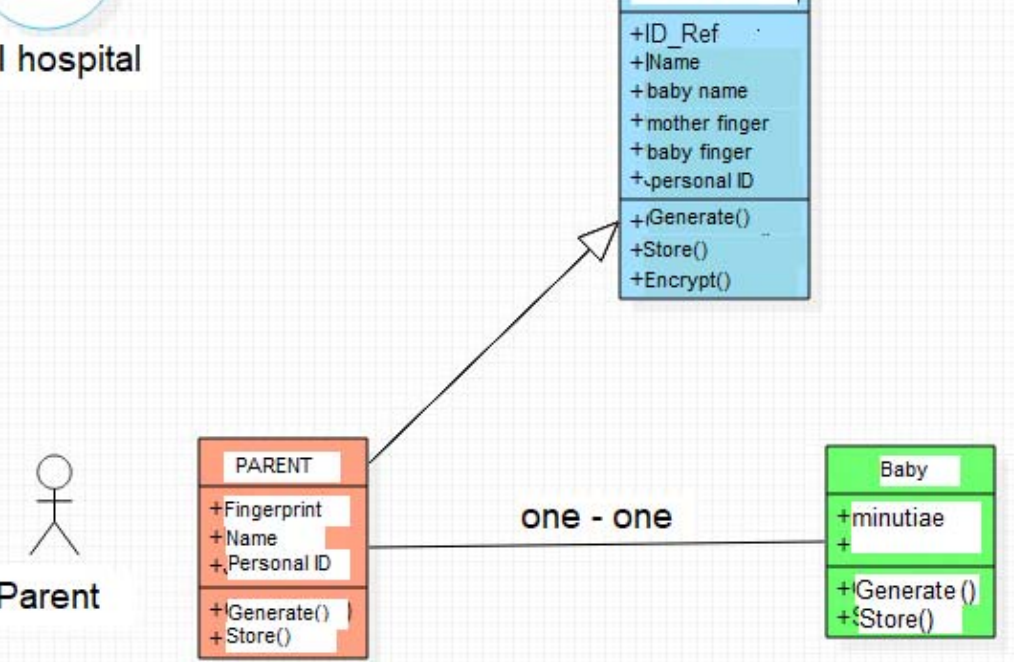

$$
\begin{aligned}
& \text { «signal» } \\
& \text { RealTime }
\end{aligned}
$$$$
\text { (from GUI birthplace) }
$$ 
This Use Case diagram shows the members of this new information system based on their roles. They are strictly determined by every role they have in hospital.
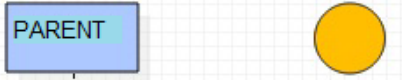

ifeline2: GUI IBRTHPLACE

Lifeline2: GUI IBIRTHPLACE
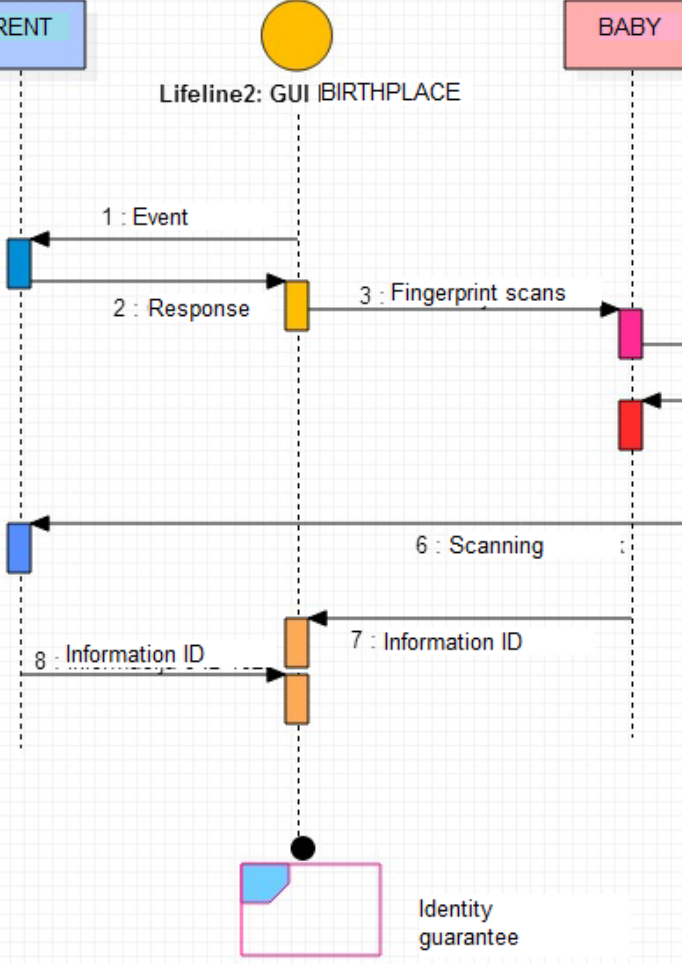

PATENT DEVICE

Figure 2 - Diagram of the information system sequences

Pис. 2 - Диаграмма последовательностей Информационной системы

Слика 2 - Дијаграм секвенци информационог система

\section{Can baby fingerprint minutiae be acquired?}

The main purpose of this device, a dual biometric fingerprint scanner, is to scan the fingerprints of the mother and the newborn baby at the same time at the very moment of childbirth. It has two fields, one larger with a classic scanning resolution of $500 \mathrm{dpi}$ and another physically smaller but with a larger scanning resolution - minimum 1000 dpi so it can make scans of a baby fingerprint that is very small. (Lalović, 2018, pp.366-379) (Lalović et al, 2016ab), (Ferguson et al, 2013, pp.6772)

In Biometry as a branch of advanced security systems, Discipline Informatics and Computing, Science Field - Natural Sciences and 
Mathematics, there is a scientific fact, better to say an axiom, that a fingerprint is formed during the prenatal period for every fetus and it stays constant in the shape of minutiae during the whole life. (Moujahdi et al, 2014, pp.189-196), (Elgendi, 2012, pp.14-25), (KaplanSandquist et al, 2014, pp.68-77), (Lalović et al, 2016ab, pp.65-81), (Lalović et al, 2015, pp.293-302)

According to many research studies realized on fingerprints of fetuses, using ultra waves and biometry scanning, the minutiae on each finger are formed by the end of $7^{\text {th }}$ month during pregnancy. It is important to mention that babies born prematurely, during $8^{\text {th }}$ month, and also by the end of $7^{\text {th }}$ month of pregnancy, have already formed fingerprints on all fingers and toes. (Anil, 2008), (Gutiérrez-Redomero et al, 2014, pp.199-207), (Elsevier, 2014, p.12), (Dahlen \& Caplice, 2014, pp.266-270)

This scientific fact is essential for our patent and this device, this research and this project realization that will provide a qualitative jump in gynaecology, midwifery and nursing in every hospital in the world.

The $100 \%$ guarantee of baby's identity and maternity for each newborn baby will be simultaneous scanning of the mother's and the baby's fingerprints at the moment of childbirth, when the mother sees her baby for the first time. Doctors and nurses measure the weight and height of the baby, and then clean one of baby's fingers with alcohol or some other liquid and place it on the smaller field of the fingerprint scanner together with the mother's finger on the larger field of the scanner so that the device scans and generates a unique ID reference for that mother-baby pair. And this is the crucial proof that a particular newborn baby is given birth from a particular mother. After a few days, when the mother and her baby are to leave the maternity ward, the check is made on the same device which confirms baby's identity via the stored ID reference of that particular mother-baby pair. That procedure will bring about new quality, it will prevent any possibility of making errors. (Lee et al, 2012, pp.1253-1254), (Juhola et al, 2013, pp.42-50), (Maček et al, 2015, pp.43-60)

Since the fingerprint minutiae - ridges and valleys are the only biometry that is formed prenatally, they can be used for the purpose of biometry identity guarantee. The whole idea for this Patent Innovation is based on this science fact confirmed by both biometry systems as computer science and gynaecology - midwifery as branch of the health care protection system. (Anil, 2008), (Gutiérrez-Redomero et al, 2014, pp.199-207), (Grzybowski \& Pietrzak, 2015, pp.117-121). 
Other biometrics such as iris recognition is unstable because, until children are $4^{\text {th }}$ year old, the pigmentation in their eyes changes in shape and color, so it cannot be used for this purpose. (IEEE, 2011, pp.32-46)

The head, the hand and the body shape and size rapidly change during growing up so it is clear why they cannot be used either. The scientific fact that the fetus fingerprint is formed prenatally by the end of $7^{\text {th }}$ month in the belly of the pregnant mother and that it stays constant throughout the whole life with the same construction of minutiae is so incredibly amazing. (Anil, 2008), (Grzybowski \& Pietrzak, 2015, pp.117121)

There are a number of various fears during the childbirth process coming from both the mother and the medical care staff in maternity wards. Based on the research carried out in Australia and New Zealand from 2009 to 2011 and 17 workshops with over 700 midwives, one of the biggest fears is dealing with the unknown $(n=32)$. This device can help in reducing a part of it (Grzybowski \& Pietrzak, 2015, pp.117-121)

All the data obtained during the process of mother's and baby's fingerprint scanning, together with the unique ID reference, are encrypted and stored into the device memory or onto a server in the encrypted form. The device is neither open access nor available for public, it is intended just for authorized nurses, doctors and midwives in maternity wards. (Gutiérrez-Redomero et al, 2014, pp.199-207), (Grzybowski \& Pietrzak, 2015, pp.117-121)

Further on, maternity is confirmed for each mother-baby pair when an authorized person - maternity ward representative and the mother enter the $\mathrm{PIN}^{2}$ code that only they possess for their data. Changing the stored data will be disabled and the identity of a newborn baby is guaranteed $100 \%$; therefore, there is no possibility of making a mistake during this process with the patent device.

In every moment, it is possible to check maternity for every baby in each maternity ward worldwide. The information stored in the device or server with its backup copy are always in the encrypted form and there is no possibility of corrupting or deleting this data. The possibility of archiving data is enabled after the confirmation of the mother that everything is normal and after the mother-baby pair has left the maternity ward - that is the moment when a need for the guarantee of maternity in the maternity ward is no longer necessary.

The last check is performed at the moment when the mother and the baby are to leave the maternity ward. The device scans the mother's and

${ }^{2}$ PIN - Personal Identification Number 
baby's fingers simultaneously, compares them with the existing encrypted data stored at the childbirth moment for that pair and if the verification is successful - It is your baby! There is no place for fear neither for mothers nor for nurses, doctors, or midwives.

With this device and procedure, a possibility of making a mistake is avoided. The device and the system guarantee baby's identity $100 \%$ for every newborn baby. It prevents any possible theft or switching of baby identities, which unfortunately probably happened in some parts of the world, especially in South-East Europe, Balkan peninsula, and countries of the former Yugoslavia. The device will now be proof and evidence of maternity for newborn babies.

The patent inventor took Maternity symbolically because, for all living beings, the strongest instinct in the nature is that of a mother. As a respect to that instinct, the inventor decided to verify the mother's fingerprint together with the baby's and to make a unique ID reference that no one could change or delete. The cost is not high for this information system so it can be installed in every maternity ward of health care systems in every country.

\section{Benefits with this new method}

This new method which combines an information system and a device for biometric identification of newborn babies based on fingerprints provides:

- proof and evidence of maternity for every newborn baby,

-no possibilities of stealing or switching identities of newborn babies,

- safety for all future parents in maternity wards,

- cost-effectivenness, and

- wide range of applications.

It is portable, small and light, as well as environmentally friendly.

For a better understanding of the functionality and application of the device and its practical realization, there are three figures that show the device from different aspects and the cross-section of the patent device.

Figure 3 shows the device for biometric identification of maternity with a digital display, a switch and two fields for fingerprint scanning. The details in the figure are marked as follows:

B - Body of device, I - Ignition switch which can be in two positions (on/off), and can be connected with timers for delayed on/off. D - Display of the device for displaying all current activities in real time, such as start of scanning, success of process, results of generating unique ID references generated during the process of fingerprint scanning. 
$\mathbf{S}$ - Set button for starting the scanning process and reading the parameters obtained by fingerprint scanning. R - Reset button for resetting the acquired and processed data, after storing them. R1 Command button to save and store data after the scanning process.

S1 - Field for fingerprint scanning of a baby's finger, much smaller than the field for mother's fingerprint scanning. $\mathbf{2} 2$ - Field for mother's fingerprint scanning, larger that the $\mathrm{S} 1$ field.

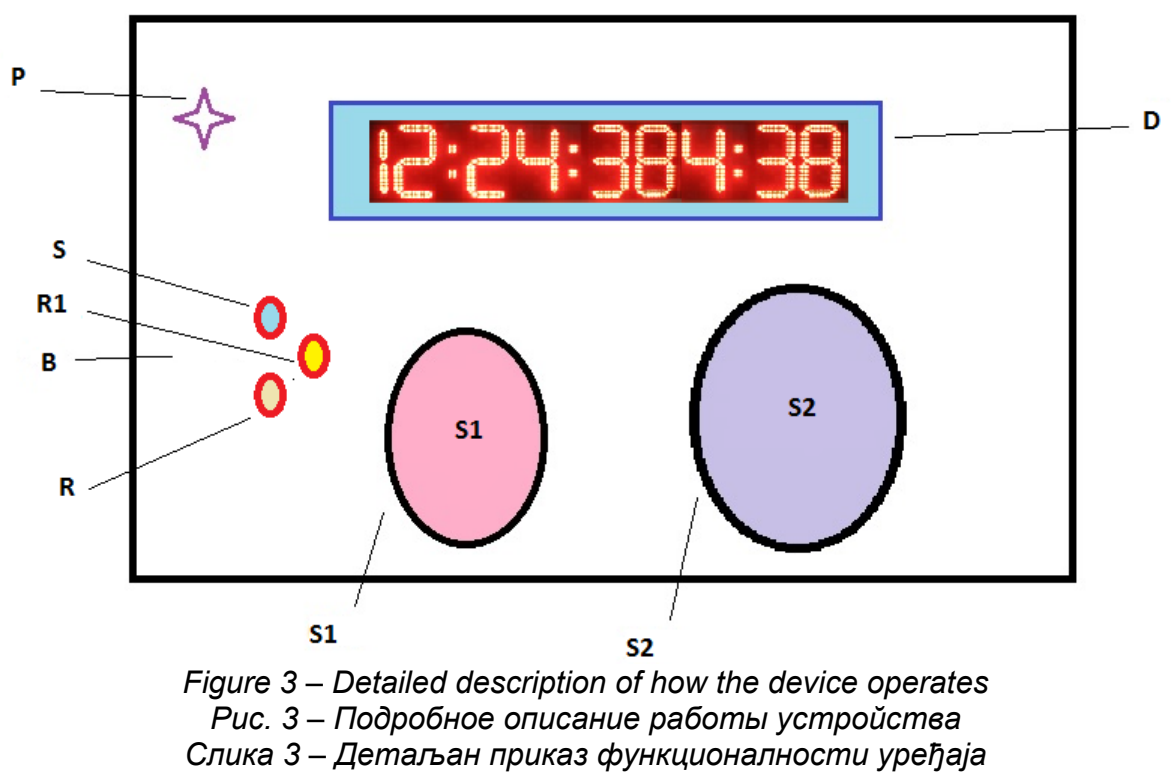

The device, started by switching $\mathbf{P}$ in the ON position, displays that it functions normally and that there are no errors. Pressing the $\mathbf{S}$ button starts fingerprint scanning on both fields (S1 and S2) at the same time, with both mother's and baby's fingers being already placed on the fields. After the scanning, pressing the R1 button will store the data and a unique ID reference is shown on the display $D$. The ID reference can be both numerical and alphanumerical (number systems can be octal, decimal, binary or hexadecimal). The main fact is that the generated ID is unique.

\section{Acquiring an algorithm in a pseudo code}

Here is the algorithm in a pseudo code listed to present the logic and all possible features of the software that the device possesses and to explain in detail how the whole system is planned to fulfill its purpose and 
to provide new quality by implementing information technologies. (Lalović et al, 2017)

\begin{tabular}{|c|c|}
\hline 01 & BEGIN \\
\hline 02 & LOOP 1 TO 3 \\
\hline 03 & FIELD-1 F1 SCANN \\
\hline \multirow[t]{2}{*}{04} & IF F1 OK THEN GOTO GENERATE UNIQE ID \\
\hline & ELSE IF LOOP < 3 GOTO END \\
\hline 05 & LOOP 1 TO 3 \\
\hline 06 & FIELD-2 F2 SCANN \\
\hline \multirow[t]{2}{*}{07} & IF F2 OK THEN GOTO GENERATE UNIQE ID \\
\hline & ELSE IF LOOP < 3 GOTO END \\
\hline 08 & GENERATE UNIQE ID \\
\hline 09 & GENERATE PIN \\
\hline 10 & ENCRYPTING DATA \\
\hline 11 & GENERATING HASH VALUE \\
\hline 12 & STORE AND SAVE DATA \\
\hline 13 & DISPLAY SUCCESS MESSAGE \\
\hline 14 & END \\
\hline
\end{tabular}

\section{Possibilities of further development}

This novel method implements a completely new device with the idea of a biometric verification of maternity and scanning of each newborn baby which can be used as a model in public health systems of all countries. Similar biometric systems can be further developed in daycare centers and in preschool institutions where there are various problems regarding constant monitoring of small children.

Beside this primary purpose, it can also can be used as part of much larger health care systems dealing with small children (pediatrics) where it can be used in providing basic data about possible allergies or some specific details of each child thus making improvements in that part of health care systems at the global level. 


\section{Conclusion}

This novel model encapsulates the benefits from three various projects: Patent device, information system and Safe birthplace project. It can improve the level of public health in the Republic of Serbia. The system is modular, it can be updated and, most importantly, it can be a basis for some future developments in biometrics systems. The device can be applied in many countries in a battle against organized crime and can help prevent theft or replacement of newborn babies, especially on territories with low IT infrastructure and technological development.

Each biometrics tends to minimize both FAR3 and FRR4 in order to be much more accurate and secure. This device accomplishes this goal since it combines two scanned data and its accuracy grows exponentially. In modern loT (Internet of things), most countries try to provide new quality of health care services, help staff in maternity wards, make the process of childbirth much easier, and more relaxed in some ways for future mothers as well as for gynaecology doctors, midwives, nurses, and others.

\section{References}

Anil, J.K. 2008. Handbook of Biometrics.USA: Michigan State University / Patric Flynn-University Of Notre Dame / Arun A. Ross-West Virginia University.

Dahlen, H.G. \& Caplice, S. 2014. What do midwives fear? Women and Birth, 27(4), pp.266-270. Available at: https://doi.org/10.1016/j.wombi.2014.06.008.

Elgendi, M. 2012. On the Analysis of Fingertip Photoplethysmogram Signals. Current Cardiology Reviews, 8(1), pp.14-25. Available at: https://doi.org/10.2174/157340312801215782.

-Elsevier. 2014. NIST publishes compression guidance for fingerprint. Biometric Technology Today, 2014(4), p.12. Available at: https://doi.org/10.1016/S0969-4765(14)70073-6.

Ferguson, S., Nicholson, L., Farrugia, K., Bremner, D., Gentles, D. 2013. A preliminary investigation into the acquisition of fingerprints on food. Science and Justice, 53(1), pp.67-72. Available https://doi.org/10.1016/j.scijus.2012.08.001

Grzybowski, A. \& Pietrzak K. 2015. Jan Evangelista Purkynje (1787-1869): First to describe fingerprints. Clinics in Dermatology, 33(1), pp.117-121. Available at: https://doi.org/10.1016/j.clindermatol.2014.07.011.

\footnotetext{
${ }^{3}$ FAR - False Accept Rate

${ }^{4}$ FRR - False Reject Rate
} 
Gutiérrez-Redomero, E., Rivaldería, N., Alonso-Rodríguez, C., SánchezAndrés, A. 2014. Assessment of the methodology for estimating ridge density in fingerprints and its forensic application. Science \& Justice, 54(3), pp.199-207. Available at: https://doi.org/10.1016/j.scijus.2013.11.004

-IEEE, 2011. Using Fingerprint Authentication to Reduce System Security: An Empirical Study, pp.32-46. In: Security and Privacy (SP), IEEE Symposium, Berkeley(CA), 22-25 May. E-ISBN: 978-0-7695-4402-1.

Juhola, M., Zhang, Y., Rasku, J. 2013. Biometric verification of a subject through eye movements. Computers in Biology and Medicine, 43(1) pp.42-50. Aailable at: https://doi.org/10.1016/j.compbiomed.2012.10.005.

Kaplan-Sandquist, K., LeBeau, M.A., \& Miller, M.L. 2014. Chemical analysis of pharmaceuticals and explosives in fingermarks using matrix-assisted laser desorption ionization/time-of-flight mass spectrometry. Forensic Science International, 235, pp.68-77. Available at: https://doi.org/10.1016/j.forsciint.2013.11.016.

Lalović, K. 2018. Patent Overview: Device for Fingerprint Identity Guarantee. Vojnotehnički glasnik/Military Technical Courier, 66(2), pp.366-379. Available at: https://doi.org/10.5937/vojtehg66-15868.

Lalović, K., Maček, N., Milosavljević, M., Veinović, M., Franc, I., Lalović, J., \& Tot, I. 2016a. Biometric Verification of Maternity and Identity Switch Prevention in Maternity Wards. Acta Polytechnica Hungarica, 13(5), pp.65-81. Available at: https://doi.org/10.12700/aph.13.5.2016.5.4.

Lalović, K., Milosavljević, M., Tot, I., \& Maček, N. 2015. Device for biometric verification of maternity. Serbian Journal of Electrical Engineering, 12(3), pp.293-302. Available at: https://doi.org/10.2298/sjee1503293I.

Lalović, K., Nikolić, J., Tot, I., \& Lalović, Ž. 2016b. Software Algorithm of Device for biometric identification of Parenthood. In BISEC 2016 - International conference in Security ICT, October 15th-Belgrade, Serbia.

Lalović, K., Tot, I., \& Andjelić, S. 2017. How to Guarantee Baby Identity Based on Fingerprint Biometry. In BISEC 2017 - International conference in Security ICT, October 18th-Belgrade, Serbia.

Lee, C., Shin, H.S., Park, J., \& Lee, M. 2012. The Optimal Attachment Position for a Fingertip Photoplethysmographic Sensor With Low DC. IEEE Sensors Journal, 12(5), pp.1253-1254. Available at: https://doi.org/10.1109/jsen.2011.2164904.

Maček, N., Borislav, Đ., Gavrilović, J., \& Lalović, K. 2015. An Approach to Robust Biometric Key Generation System Design. Acta Polytechnica Hungarica, 12(08), pp.43-60. Available at: https://doi.org/10.12700/aph.12.8.2015.8.3.

Moujahdi, C., Bebis, G., Ghouzali, S., Rziza, M. 2014. Fingerprint shell: Secure representation of fingerprint template. Pattern Recognition Letters, 45, pp.189-196. Available at: https://doi.org/10.1016/j.patrec.2014.04.001. 
НОВЕЙШИЙ МЕТОД ИДЕНТИФИКАЦИИ НОВОРОЖДЕННОГО РЕБЕНКА, ОСНОВАННЫЙ НА ОТПЕЧАТКЕ ПАЛЬЦА

Комлен Г. Лалович ${ }^{a}$, Иван А. Тот ${ }^{6}$, Младен Б. Трикошб $^{б}$

а КИТ - Колледж информационных технологий,

г. Белград, Республика Сербия

${ }^{б}$ Университет обороны в г. Белград, Военная академия,

Кафедра информационных систем и телекоммуникационной инженерии,

г. Белград, Республика Сербия

ОБЛАСТЬ: Информационные технологии (ИТ), патент

ВИД СТАТЬИ: оригинальная научная статья

ЯЗЫК СТАТЬИ: английский

Резюме:

В данной работе описан новый метод биометрической идентификации новорожденных детей в родильных домах, на основании минуций (признаков) отпечатка пальца. Информационная система комбинирует все существующие языки программирования, такие как: Java u Python в объектноориентированном программировании, C язык для структурного программирования устройств (линейных) u SQL для хранения зашифрованных данных в системе управления реляционными базами данных. Кроме того, используется RSA алгоритм ассиметричного шифрования и ключи (пароли) для хранения зашифрованных минуций отпечатков пальцев. Информационная система, внедряет устройство для биометрической идентификации материнства в виде одновременного двумерного биометрического сканера, предоставляющего данные об отпечатке пальца матери и новорожденного ребенка, непосредственно после его рождения, что в течение дальнейшего процесса полностью гарантирует предотвращение потенциальной опасности от подмены новорожденного ребенка, так как приобретенные данные сгенерированы в единый ИД код, зашифровав биометрические данные, с возможностью отмены. В статье мы представляем новейшую систему, основанную на снятии отпечатков пальца, которую мы разработали.

Ключевые слова: биометрия, отпечаток пальца, безопасность, новорожденный ребенок, метод, информационная система.

НОВИ МЕТОД ЗА ОДРЕЪИВАњЕ ИДЕНТИТЕТА

НОВОРОЪЕНЧЕТА, ЗАСНОВАН НА БИОМЕТРИЈИ ОТИСКА ПРСТА

Комлен Г. Лаловић ${ }^{\mathrm{B}}$, Иван А. Тот ${ }^{6}$, Младен Б. Трикош $^{6}$

а ИТС - Висока школа струковних студија за информационе технологије, Београд, Република Србија

${ }^{5}$ Универзитет одбране у Београду, Војна академија,

Катедра информационих система и телекомуникационог инжењерства,

Београд, Република Србија 
ОБЛАСТ: информационе технологије, патент ВРСТА ЧЛАНКА: оригинални научни чланак ЈЕЗИК ЧЛАНКА: енглескИ

\section{Сажетак:}

Овај рад презентује нови поступак биометријске идентификације новорођених беба у породилиштима који је заснован на минуцијама отиска прста. Информациони систем који је реализован комбинује све данашње програмске језике као ито су: Јава, Пајтон у објектно-оријетисаном програмирању, C програмски језик за програмирање уређаја као структирни (линијски) и SQL систем за управљање релационим базама података за чување. Поред тога, користи се RSA асинхрони шифрарски алгоритам и кључеви за чување шифрованих вредности минуција отиска прста. Инфрормациони систем имплементира урађај за биометријску идентификацију родитељства као дуални биометријски скенер који даје податке о отиску прста мајке и бебе при самом моменту рођења, што отклања опасност од замене новорођенчета. Генеришући јединствене ID референце и шифрујући те податке са цанцелабле биометријом. развили смо један потпуно нови систем и поступак заснован на минуцијама отиска прста.

Кључне речи: биометрија, отисак прста, безбедност, беба, метода, информациони систем.

Paper received on / Дата получения работы / Датум пријема чланка: 29.08.2018.

Manuscript corrections submitted on / Дата получения исправленной версии работы / Датум достављања исправки рукописа: 26.11.2018.

Paper accepted for publishing on / Дата окончательного согласования работы / Датум коначног прихватања чланка за објављивање: 28.11.2018.

(C) 2019 The Authors. Published by Vojnotehnički glasnik / Military Technical Courier (www.vtg.mod.gov.rs, втг.мо.упр.срб). This article is an open access article distributed under the terms and conditions of the Creative Commons Attribution license (http://creativecommons.org/licenses/by/3.0/rs/).

(c) 2019 Авторы. Опубликовано в «Военно-технический вестник / Vojnotehnički glasnik / Military Technical Courier» (www.vtg.mod.gov.rs, втг.мо.упр.срб). Данная статья в открытом доступе и распространяется в соответствии с лицензией «Creative Commons» (http://creativecommons.org/licenses/by/3.0/rs/).

() 2019 Аутори. Објавио Војнотехнички гласник / Vojnotehnički glasnik / Military Technical Courier (www.vtg.mod.gov.rs, втг.мо.упр.срб). Ово је чланак отвореног приступа и дистрибуира се у складу са Creative Commons лиценцом (http://creativecommons.org/licenses/by/3.0/rs/).

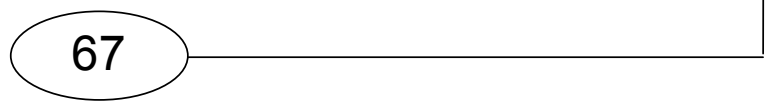

